\title{
'I Am that I Am' (Ex. 3.14): from Augustine to Abhishiktānanda-Holy Ground Between Neoplatonism and Advaita Vedānta
}

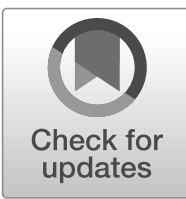

\section{Daniel Soars ${ }^{1}$}

Published online: 7 July 2020

(C) The Author(s) 2020

\begin{abstract}
We shall revisit a debate which has been going on at least since pioneering British Indologists like William Jones first encountered the 'Brahmanic theology' we now know as Vedānta, namely, the nature of the relationship - if anybetween certain forms of 'western' and 'Indian' idealisms, and how these metaphysical systems have influenced Christian theology. Specifically, we look at the question of possible thematic and conceptual convergences between Neoplatonism and Advaita Vedānta, and argue that significant parallels can be found in their common conception of the Absolute as Being. Rather than attempt a comprehensive overview of the two systems, we take the divine 'I AM' revealed to Moses in Exodus 3.14 as the locus classicus of Christian philosophical interpretations of God as Being itself, and explore how four seminal figures read this passage in light of Neoplatonic and Vedāntic influences. We shall see that similarities and divergences in the readings of Augustine, Thomas Aquinas, Meister Eckhart and Henri Le Saux can be understood in terms of how they negotiate the relation between the One and the many, or between 'being' and 'knowing'. The more these figures allow themselves to be influenced by Neoplatonism and Advaita Vedānta, the more we see any clear ontological distinction between creature and Creator start to break down. This verse, therefore, proves to be an unusually fruitful test case for exploring the relation between the underlying Neoplatonic and Vedāntic metaphysics which structure varying Christian interpretations of it.
\end{abstract}

Keywords Exodus 3.14 · Neoplatonism · Advaita Vedanta

Daniel Soars

djs85@cam.ac.uk

1 Faculty of Divinity, The University of Cambridge, Cambridge, UK 
'If properly understood, these Vedânta teachings may, though under a strange form, bring us very near to the earliest Christian philosophy, and help us to understand it, as it was understood by the great thinkers of Alexandria'. (MaxMüller 1919, p.124).

The question of the possible relationship between some forms of Greek and Indian theological idealisms - specifically, between (neo)-Platonism and (Advaita) Vedāntais a long-standing one. At stake are two distinct issues: an empirical one of historical cross-fertilization between the two traditions, on the one hand, and a hermeneuticalphilosophical one of structural and conceptual analogies which may or may not result from actual instances of historical encounter, on the other. In the first case, scholarship has tended to focus on perceived parallels between the writings of Plotinus (c.205$270 \mathrm{CE}$ ) and certain resonant conceptual themes in the Upanișads (the 'end' — anta - of the Vedas) — with debate centring around whether or not these parallels provide evidence of direct historical contact between Plotinus and the Indian sources. In the second case, the comparative discussion tends to bracket the question of actual historical borrowing across the traditions as a largely unanswerable one, and concentrates instead on trying to distinguish between merely surface similarities and deeper philosophical convergences in certain doctrines we find in a Neoplatonist like Plotinus and a Vedāntin like Śamkara $(c .788-820 \mathrm{CE}){ }^{1}$ In order to offer some contextual background to the two traditions, I will briefly review the historical debate, but my aim here is to contribute to the comparative theological-philosophical discussion, not to put forward an argument (one way or the other) for actual historical contact.

I do this from a slightly unusual angle, by focusing on a single verse from the Hebrew scriptures (Exodus 3.14) and how it has been read by four figures in the Christian tradition. The justification for examining possible parallels between Hellenic Neoplatonism and Sanskritic Vedānta through a Judaeo-Christian lens might not seem obvious, but this one verse provides a particularly concentrated and fruitful test case for our conceptual experiment, given its long interpretation history and appeal to a certain philosophical temperament within Christian theology. Specifically, this verse has proven to be a locus classicus of Christian philosophical interpretations of God as 'Being' itself. ${ }^{2}$ By exploring the fundamental question of the conceptual and metaphysical identity of God and Being in what we might call 'Christian Platonism' - specifically, as this question of 'God-Being' is manifested in the long and varied interpretation history of a single scriptural verse and its hidden, or 'mystical' meaning - I am indebted to the work of Werner Beierwaltes (Beierwaltes 1972, p.1-64). ${ }^{3}$ Importantly for my argument, it is also a verse to which certain figures in the

\footnotetext{
${ }^{1}$ Some scholars reject the traditional 788-820 dating, which emerged only in the late nineteenth century based on an alleged writing of Śamkara that is now deemed spurious. No one disagrees that Śamkara likely lived about 32 years, but he is now regularly dated as having lived "c. 700 CE." To follow this up in more detail, see Malkovsky 2001, p.1-8. Either way, this makes no material difference to my argument since the suggestion is not that Plotinus and Śamkara ever actually met.

${ }^{2}$ The broader argument for the use of Greek thought as a conceptual vehicle for expressing Christian beliefs particularly Platonic concepts as developed and structured by key pagan figures in the early centuries of the Christian era, like Plotinus, Porphyry (232-305), Iamblichus (245-326) and Proclus (412-485) - has been made persuasively elsewhere (e.g. O'Meara 1982), so it is not my intention to engage directly in this metaconversation here.

${ }^{3}$ Beierwaltes 1972, only exists in the original German. When the citations I have used are crucial to my argument, I have translated them myself into English.
} 
Vedāntic traditions have pointed in support of a non-dualistic (a-dvaitic) reading of the 'relation' between the world and God in Christianity. My aim is to focus on four Christian appropriations of this characteristically Platonic and Vedāntic philosophical identification of the Absolute with 'Being' as such, in order to explore how far arguments for convergence between (neo)-Platonism and (Advaita) Vedānta can be pushed.

I will begin by looking at how Ex. 3.14 was understood by St Augustine (354$430 \mathrm{CE}$ ), to see how his exegesis is shaped by his well-attested indebtedness to Platonism. I will then turn to two medieval figures who were influenced by Augustine and, to greater or lesser extents, by the Platonism which had formed him: Thomas Aquinas (1225-74) and Meister Eckhart (1260-1328) will offer an interesting interim comparison in their own right, given that they are often seen as representing quite different aspects of the Christian theological tradition - the 'scholastic' and the 'mystical'. Finally, I will turn to a twentieth century Benedictine, Henri Le Saux (1910-73), who became better known as Swami Abhishiktānanda after he moved to India to begin a lifelong struggle of trying to reconcile his Roman Catholic Christianity (coloured, certainly, by Augustine, Aquinas and Eckhart) with the spiritual and metaphysical frameworks of Advaita Vedānta. If there really are deep metaphysical convergences between (neo)-Platonism and (Advaita) Vedānta, we might reasonably expect to find some thematic continuities running through all four figures. Of course, by focusing on their interpretations of a single verse, we cannot hope to provide a comprehensive survey of all the possible similarities and dissimilarities between the two systems, but excellent studies of this kind already exist (e.g. Staal 1961, Harris 1981, Hacker 1995 and Paulos Gregorios 2002). The purpose of this essay is to put the debate into sharp focus, by pointing a single beam at an unusually pregnant scriptural passage which has attracted the attention of Christians (and Vedāntins) influenced by both Platonism and Vedānta. While Le Saux's reading is distinguished from the other three by the fact that he studied Vedānta, we will see that he picks up on some of the same (Neoplatonic) themes as the earlier Christian thinkers we examine. ${ }^{4}$ By tracing the contours of their differing interpretations, we will be able to see precisely which conceptual lines converge and where comparison might break down under the weight of doctrinal tensions that are less easily reconcilable.

\section{Parmenides, Plato and 'Brahmanic Theology'}

In a fascinating observation in one of his letters, the pioneering East India Company scholar of Indology, William Jones (1746-1794), makes the following assessment of the 'Brahmanic theology' he is encountering in Bengal: 5

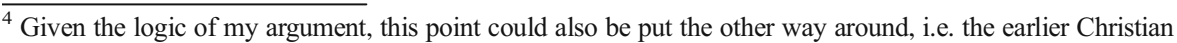
thinkers - insomuch as and to the extent that they were influenced by Neoplatonism - were conceptually 'as if' influenced by Advaita Vedānta, even if not historically so, since they thought in some ways like Advaitins. ${ }^{5}$ Along with Charles Wilkins (1749-1836) and Henry Thomas Colebrooke (1765-1837), William Jones is widely recognised as one of the most important Orientalists of the Company era in India. Supported by the then Governor-General, Warren Hastings (1732-1818), the pioneering work of these civil servant scholars opened up Indology as an academic discipline for future generations. For more on this period, see the detailed and influential study by Kopf 1969 .
} 
'The doctrine is that of Parmenides and Plato, whom our Berkley [sic] follows, and I am strongly inclined to consider their philosophy as the only means of removing the difficulties which attend the common opinions concerning the Material world'.6 (App 2009, p.18)

The 'Brahmanic theology' to which Jones refers is the systematic tradition of commentary, exegesis, and philosophical interpretation of the Upanișads, better known to us today as Vedānta. By comparing Vedāntic teachings with those found in Parmenides and Plato, Jones is entering a debate which has continued ever since. As I have already outlined, this is a debate which can take two different directions - the first, an empirical-speculative investigation into possible historical contact between Platonism and Vedānta. This first issue has tended to revolve around questions over the possible Eastern (where this could mean anything from Indian to Persian or Egyptian) influences on the philosophy of Plotinus, the founder of Neoplatonism. ' That there were some 'Eastern ' influences on Plotinus's thought seems undeniable; he was born in Egypt, and studied in Alexandria where there were already Brahmins and Buddhists by the first century CE. Indeed, Plotinus's student and editor, Porphyry, tells us that the Platonic teaching his master received in Alexandria from Ammonius Saccas inspired him to find out more about Persian and Indian thought (Porphyry, On the Life of Plotinus and the Order of His Books, in Armstrong, Ennead I, 1969). As a result, Plotinus joined the Emperor Gordian's military expedition to Persia, perhaps hoping to go on from there to the subcontinent, but never got as far as India. ${ }^{8}$ Whether or not he went on to read Indian metaphysical texts or, indeed, discuss them with Brahmins in Alexandria is a fascinating but probably unresolvable question. Nevertheless, the issue of whether the similarities between elements of Neoplatonism as found in Plotinus and aspects of Indian thought are merely the result of coincidental osmosis, a philosophia perennis, or evidence of more direct influence captured the imagination of certain scholars in the twentieth century. Some, like E. Bréhier, advocated a strong 'Oriental hypothesis', while others, like A.H. Armstrong and J. Rist argued that the seeds of all of Plotinus's key doctrines could be found closer to home, in his own Hellenistic context. ${ }^{9}$

What I am more interested in here is Jones's suggestion that there is something of fundamental philosophical importance in the Greek and Indic traditions which may be 'the only means of removing the difficulties which attend the common opinions concerning the material world'. His allusion to Berkeley would imply that the means he has in mind - and which he claims to find in similar form in India and in Greece - is some kind of philosophical idealism. Idealism is a term which is, of course, notoriously

\footnotetext{
${ }^{6}$ The citation comes from William Jones in Cannon 1970, p. 669-70, and is taken here from App 2009, p.18.

${ }^{7}$ For an overview of the scholarship on this question, see Albert M. Wolters, 'A Survey of Modern Scholarly Opinion on Plotinus and Indian Thought', in Harris 1981, p.293-309. While the terminology of 'Middle' and later ('Neo') Platonism is widely used, it should be remembered that these distinctions themselves are not neutral historical labels since they imply stronger demarcations of the Platonic tradition than some scholars (or perhaps even Plotinus himself!) would be willing to accept.

${ }^{8}$ For more on this episode, see Gregorios 2002, p.13-17.

${ }^{9}$ See R.T. Ciapola, 'Bréhier and Rist on Plotinus', in Gregorios (2002), p.71-79. For more general overviews, see R.K. Tripathi, 'Advaita Vedanta and Neoplatonism' and C.L. Tripathi, 'The Influence of Indian Philosophy on Neoplatonism' in Harris (1981).
} 
polyvalent and liable to misunderstanding even within western philosophical traditions, so trying to overlay it onto a thought system not conceived with these categories in mind is fraught with exceptional difficulty. ${ }^{10}$ As if this were not enough reason to be wary, several different Vedāntic schools developed in India towards the end of the first millennium of the Common Era and into the second-each offering distinctive accounts of the metaphysical worldview found in the Upanișads ${ }^{11}$ — and the question of how far any of them neatly map on to what a western philosopher is likely to understand by 'idealism' is a complex one. ${ }^{12}$ With these provisos in mind, however, if we can take 'the doctrine of Parmenides and Plato' to be 'idealist' in the minimal sense of claiming the dependency or derivation of the material realm upon or from the spiritual, it would be reasonable to see the 'Brahmanic theology' Jones has in mind as similarly 'idealist'. 13

The dominant school of Vedānta (in the sense that it was the archetype against which doctrinal opponents would, explicitly or implicitly, set their own arguments) became the non-dual or 'advaita' (literally, 'not-two') form as found in its most celebrated exponent, Samkara. Typically taken to be a reading of scripture which holds that there is, transcendentally speaking, only one changeless ground of being (Brahman) and that the manifold world of experience is, from an ultimate perspective, merely an 'appearance' of this simple and undivided Reality, Advaita Vedānta is usually seen as a form of idealism in which the world is either metaphysically illusory or, at the very least, ontologically dependent on its hyper-ground which is Brahman. ${ }^{14}$ Given Plotinus's doctrine of the emanation of all being from the One who is 'beyond being', it is not difficult to see why Plotinus and Śamkara have proven to be amenable to scholarly comparisons of (Neo)-Platonism and Vedānta en gros. The key task for our purposes is to identify the precise nature of the philosophical and conceptual themes which have drawn scholars to ask in the first place about possible analogies between the two systems - for it is these themes which we would expect to find in Christians influenced by (Neo)-Platonism, like Augustine, Aquinas and Eckhart, and Christians influenced by Vedānta, like Abhishiktānanda, if there really are connections between these forms of Greek and Indian idealisms.

The most detailed full-length study of the issue of philosophical convergences specifically between Neoplatonism and Advaita Vedānta suggests that we are likely to find significant parallels and divergences in our four Christian figures (Staal 1961). As well as important differences between the two systems, J.F.

\footnotetext{
${ }^{10}$ That is not to say that a similar kind of distinction between realism and idealism is utterly unknown in the Indian tradition because disputes between Advaita and, say, the Nyāya-Vaiśeșika school clearly suggest otherwise, but only that these terms come laden with preconceptions when used from within their Western (Graeco-Roman and later primarily German) philosophical contexts.

${ }^{11}$ For a comprehensive overview of these different interpretations of the Upanișadic revelation, see Lott 1980.

12 To follow up this question of how far different Indian philosophical systems can be considered 'idealist', and what precisely this might mean, see Pandey 2015, p.26-44.

13 Jones's reference to Berkeley here is potentially misleading as the Irish bishop's form of subjective idealism seems quite different from anything that Parmenides or Plato put forward, and my focus here is on how far Vedānta resembles Platonic idealism (i.e. minimally, that the physical world is ontologically dependent on and, in some sense, inferior to intelligible spiritual reality, not that the physical world can be reduced to a bundle of perceptions).

${ }^{14}$ For a historical survey of 'realist v idealist' interpretations of Advaita, see Malkovsky 2001, p.46-50. In many ways, these debates resemble similar ones in Platonism scholarship, and often have as much to do with what one means by 'realist' and 'idealist' as they do with what Śamkara and Plato actually said (or meant).
} 
Staal contends that there are deep conceptual resonances to be found in certain doctrines - not least, in the focus in both systems on the Absolute as unlimited Being and on union with the Absolute through self-knowledge. ${ }^{15}$ While it might be objected that the Absolute in Plotinus's Neo-Platonism is 'beyond being' (Ennead V.5.6), ${ }^{16}$ Staal sees no contradiction between this and Śamkara's affirmation that Brahman is Being (sat), for both intend the same thing-that the Absolute is beyond qualified and intelligible being. Both Plotinus and Śamkara, moreover, would agree, Staal argues, that the physical world is a-dvaita with the Absolute; 'For what comes from him [the One] has not been cut off from him, nor is it the same as him...' (Ennead V.3.12). If similar conceptions of the Absolute and its relation to the physical world can be found in Neoplatonism and Vedānta - conceptions which seem to indicate similar kinds of religious idealism (in which the material derives from and is dependent on the spiritual) - then it is also true to say that the implications of this non-dualism between the many and the One are similar in both ancient systems. If the Absolute is the unlimited plenitude of Being, then we find God/Brahman not by looking 'outside' for 'anything more', but by turning inward and realizing our presence in the All:

'But if "you will seek nothing anymore", however will this happen to you? Now it is because you approached the All and did not remain in a part of it, and you did not even say of yourself 'I am just so much', but by rejecting the 'so much' you have become all-yet even before this you were all; but because something else came to you after the "all" you became less by the addition: for the addition did not come from being-you will add nothing to that - but from non-being'. (Ennead VI.5.12).

'Whatever is made of clay, like a pot and so on, is only and always entirely nothing but clay. Similarly, all this that is the effect of the Real, is the Real itself, and entirely nothing but the Real. Because nothing exists, anywhere, anytime, other than the Real, That is the Truth, your own Self. Therefore, That thou art, supremely serene, pure, the Supreme, the non-dual Absolute'. (Vivekacūạamani 253) ${ }^{17}$

We shall now focus on how these two related conceptual themes-viz. equating the Absolute with unlimited Being and what we might call conversion or subjectivity (recognising that 'I' - in my deepest Self — am the 'All') — feature in Augustine, Aquinas, Eckhart and Abhishiktānanda, and, in particular, in their readings of Ex. 3.14.

\section{Being, Knowing and Exodus 3.14}

As intimated by W. Jones, the link between Being and origins, and the identification of the first principle of Being with God (theos), was clearly present in Greek thought

\footnotetext{
${ }^{15}$ M. Just sees Plotinus's focus on subjectivity (self-knowledge) and mystical union, in contrast to a more typically 'Hellenic' emphasis on rationality, clarity and objectivity as the reason to suppose that Plotinus might have had 'Eastern' influences. See Just 2013, p.3.

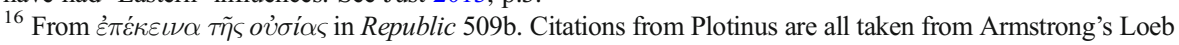
version.

${ }^{17}$ It should be noted that there is some scholarly disagreement over whether this text can authentically be attributed to Śamkara or is the work of a later Advaitin. To follow this up, see the Introduction to Grimes 2004. In any case, this verse would be acceptable to any Advaitin, given that it is really just a gloss on Chāndogya Upanișad VI.
} 
before Plato (c.428-347 BCE). Along with other pre-Socratic philosophers, ${ }^{18}$ Parmenides ( $c$. late sixth-early fifth century BCE) identifies Being in ways which remained influential not only in the later Platonic tradition but also on the Christian thinkers we will discuss. That Parmenides' enigmatic poem ('On Nature') is in part a conversation with a goddess suggests that he saw his search for an understanding of ultimate origins as a religious one, an encounter with the ground of existence is also an encounter with the divine. The goddess explains that Being is 'ungenerated and imperishable, entire, unique, unmoved and perfect', (Fragment 8.1-4 in Coxon 2009) and, as such, all that is and can be thought, since what 'is not' lies down a path which cannot be trodden; there simply is no-thing there to know or to think. ${ }^{19}$

Precisely, these defining characteristics of 'God-Being' are evident in the first philosophical interpretations of the Greek Septuagint translation of Exodus 3.14 (ego eimi ho on). From Philo of Alexandria (20-50 CE) to Patristic writers like Gregory of Nazianzus (329-390 CE) and Gregory of Nyssa (335-395 CE), the basic conceptual distinction is the one we find in Parmenides - that is between 'Being' (now identified by Christian theologians with God as 'He who is') and non-being. Following the goddesses' description, the divine name given to Moses, according to these biblical exegetes, reveals God as eternal, unchanging, limitless Being. ${ }^{20}$ These onto-theological Parmenidean themes, developed and systematised by Plato, are taken up in Christian theology from early on in the tradition via the mediations of so-called Middle Platonists like Plutarch (46-120 CE) and, especially, Neo-Platonists like Plotinus and his student, Porphyry (Beierwaltes 1972, p.16-24). By identifying the Absolute as either Being itself or as the One 'beyond Being', Greek philosophy provided the metaphysical resources for highly sophisticated Christian interpretations of the divine name revealed to Moses at the burning bush.

As we explore how four seminal thinkers understood the enigmatic divine name revealed on Mount Horeb (Ex. 3.14, 'I am he who is'/'ehyeh 'asher 'ehyeh) ${ }^{21}$, we will see that each of their interpretations is distinctively both Platonist (and, in Le Saux's case, Vedāntic) and Christian, but that it is their way of conceptualising the relationship between 'thought' and 'being', and between 'knowledge' of God and 'identity' with God, which distinguishes them. In order to bring out these continuities and differences more clearly, I have chosen only one figure who can be thought of fairly uncontroversially as a 'Christian Platonist' (or a Platonist Christian), namely, St Augustine; when it comes to the other three, some may doubt the extent to which they can be unambiguously described as 'Platonist' (in the case of Thomas Aquinas), 'Christian' (in the case of Meister Eckhart) or either 'Christian' or 'Platonist' in the case of Swami Abhishiktānanda (Henri le Saux).

\footnotetext{
${ }^{18}$ Such as the even earlier figure of Anaximander (c.611-546 BCE).

${ }^{19}$ For more on the relationship between 'thought' and 'being' in Parmenides, see Perl 2014, esp. p.3-17.

${ }^{20}$ Cf. Beierwaltes 1972, p.14. 'Dieses Sein meint zeitfreie Gegenwärtigkeit, unwandelbare Vollendetheit, reine Wirklichkeit und unbegrenztes In-sich-Sein'.

${ }^{21}$ New Jerusalem Bible translation. Clearly, this verse raises all sorts of philological, exegetical and theological questions, which I do not pretend to solve in this paper. My focus will solely be on the four thinkers under discussion.
} 


\section{Augustine (354-430 CE)}

Just as previous figures like Philo and the Church Fathers had seen in this pivotal verse in Exodus a confirmation of God's eternal ('ungenerated and imperishable'), simple ('entire and unique') and unchanging ('unmoved and perfect') nature, so Augustine follows these Platonic themes in his interpretation of God's 'I am'. In particular, in his early work On True Religion (De vera religione-written c.390, only about 3 years after being baptised a Christian), in some of his commentaries on the Psalms (Augustine 1979, esp. of Ps. 38 and 101), and in his Confessions, Augustine focuses on the eternity and immutability of 'He who is'. ${ }^{22}$

In a remarkable passage in the Confessions, the then bishop recounts his discovery of God's nature as Being itself by means of a 'conversion' or turning inward of his gaze:

'By the Platonic books I was admonished to return into myself. With you as my guide I entered into my innermost citadel... When I first came to know you, you raised me up to make me see that what I saw is Being, and that I who saw am not yet Being... and I found myself far from you 'in the region of dissimilarity' and heard as it were your voice from on high: 'I am the food of the fully grown; grow and you will feed on me. And you will not change me into you like the food your flesh eats, but you will be changed into me'. ...And you cried from far away: 'Now, I am who I am' (Exod. 3:14)'. (Augustine 2008, VII.x.16).

It was thanks to these 'Platonic books' that Augustine was able to leave behind his Manichean dualism and gradually 'seek for immaterial truth' (Augustine 2008, VII.xx.26) and find God as Spirit, as He who 'truly is'. He worked through the consequences of this discovery in his early writings (such as De vera religione) before paying Exodus 3.14 any particular attention, ${ }^{23}$ but his subsequent readings of this verse confirming God as 'Being' itself helped to establish 'He who is' as "the main divine name in the Latin West" (Zum Brunn 1988, vii). The stage had been set for Augustine by the Platonism of figures like Plotinus, ${ }^{24}$ Porphyry and Marius Victorinus (Augustine 2008, VIII.ii.3)-indeed, without this Neoplatonist philosophy, Beierwaltes sees Augustine's concept of God and Being as simply unthinkable (Beierwaltes 1972, p.37). ${ }^{25}$

Three themes which appear in the above passage and run as leitmotifs throughout Augustine's work are particularly pertinent to the relation between 'knowing' and

\footnotetext{
${ }^{22}$ Beierwaltes argues that Augustine's distinctive emphasis is on God's 'eternity' (1972, p.27) while Zum Brunn sees it as being more on 'immutability' - cf. Zum Brunn 1988, p.104-5. Given divine simplicity, though, this choice of emphasis only reflects a conceptual distinction, and not an ontological one because God's 'eternity' is not an attribute which stands in contrast to God's 'immutability'.

${ }^{23}$ For more on the relative chronology of Augustine's encounter with Platonism, his conversion to Christianity and his key works, see Zum Brunn 1988, p.98-99.

${ }^{24}$ Plotinus's 1984/1988 influence can be seen overtly in the passage from Augustine's Confessions quoted above - not least in the idea of 're-turning inward' (cf. Ennead V.1.1) and the physical world being a 'region of dissimilarity' from the One (cf. Ennead I.8.13, from Plato, Statesman 273d).

25 'Wie eine umfängliche und teilweise intensive Forschung gezeigt hat, ist Augustins Begriff von Gott und Sein nicht denkbar ohne die Philosophie des Neuplatonismus, insbesondere Plotins und Porphyrys; Marius Victorinus kommt eine für Augustin bedeutende Vermittlerrolle in bezug auf neuplatonische Philosopheme zu'. It is important to note, alongside Beierwaltes' emphasis on Neoplatonism, that Augustine was also influenced by the 'middle Platonism' of Philo, via the Alexandrian Christian thinkers Clement (150-c.215 CE) and Origen (184-253 CE). See Norris Clarke 2009, p.72, and Boland 1996, p.38-47.
} 
'being' as a conceptual seam which links Neoplatonism and Vedānta. Firstly, Augustine establishes a dialectic between 'Being' and 'nothingness' (nihil), which makes his ontology not merely speculative but anagogical (Beierwaltes 1972, p.27). ${ }^{26}$ By being 'raised up' (through divine grace), Augustine sees that he is 'not yet Being', since being 'created' means precisely to stand out (existere) between, as it were, the absolute Being of 'He who is' and the absolute nothingness of non-existence. ${ }^{27}$ Secondly, we can see in the passage that 'at-one-ment', or salvation, for Augustine, begins with 'finding oneself far from God, in the region of dissimilarity' and consists in nothing other than turning back to God by 'changing into Him', since it is up to the creature '...to settle either in Being or in a state close to nothingness, according to whether or not it confirms the "wanting-to-be" (esse velle) rooted in it, that is to say the desire of a greater participation in Being than the one which is its own from the simple fact of existing' (Zum Brunn 1988, p.191). Thirdly, this process of being brought back (by divine grace) to one's own essence by drawing ever closer to the 'first Essence' is effected by a Plotinian 'return into oneself', a remembering of what one truly is. ${ }^{28}$ As Zum Brunn puts it,

'...if the Immutable is not envisaged from the point of view of a metaphysics of conversion, the Augustinian definition of God-Being is cut down, for Immutable Being is only reached at the conclusion of a return that transforms the soul to its likeness, in virtue of the principle according to which the like is only known by the like. It is why, like that of its Platonic models, this ontology is essentially an ontology of spiritual life'. (Zum Brunn 1988, p.101-2). ${ }^{29}$

This spiritual life, however, is not one, in the fullest sense, which Augustine thought he could find in the 'Platonists' books' because while they had shown him the vision of 'what truly is' (Augustine 2008, VII.xx.26) they could not take him there. This 'way' he came to find in the Christian scriptures and, in particular, in the mediatory figure of Christ (Augustine 2008, VII.xx.27). This is why Augustine's reading of Exodus 3.14 is thoroughly Platonic but also distinctively Christian, because while he uses the language of a Neoplatonic metaphysics of return (i.e. that conversion is about ontological assimilation to 'He who is'), he also uses overt eucharistic imagery of 'feeding, 30 and draws parallels between the Ego sum qui sum of Mount Horeb and the 'I am'

\footnotetext{
26 'Eine Scheidung setzt er [Augustin] zwischen dem wandelbaren, weil der Zeit unterworfenen, welthaft Seienden, und dem Prinzip oder Grund dieses Seienden...'

27 'Absolute Being... is summum esse, ipsum esse, uere esse, or quod est, also expressed, with the help of the Exodus verse 3:14, by the personal forms ego sum qui sum, qui est, and in an abbreviated way sum est. In contrast, the ontological deficiency, which characterizes our existence as long as it is not regenerated by the conversion to Being, Augustine calls according to the circumstances minus esse, non uere esse, or still utcumque esse'. Zum Brunn 1988, p.2. Cf. Conf. VII.xv (21): 'So all things are real insofar as they have being, and the term 'falsehood' applies only when something is thought to have being which does not'.

${ }^{28}$ It should be noted that while the so-called early Augustine, around 389, seems to have argued that it is 'up to us' to turn back to God through a structured programme of Neoplatonic cultivation of the virtues, the 'late' Augustine, around 430, would vehemently deny such a possibility of human-instigated return to God-it is only God who turns us around, and more specifically only those of us who are timelessly predestined, towards salvation.

${ }^{29}$ As noted above, this note of likeness appears in the texts of the 'early Augustine' - the later Augustine would state that the creature is utterly unlike the creator whose ways are inaccessible to human intellects.

${ }^{30}$ For more on Augustine's (and Aquinas's) Christological interpretations of Ex. 3:14, see Soskice 2014, p.190-207, here p.203.
} 
sayings in John's Gospel. ${ }^{31}$ It might be considered anachronistic to label Augustine a 'mystic', but in his desire for ever greater union with the God in whom 'we live and move and are' (Acts 17.28, cited in Augustine 2008, VII.ix.15), he perceives the 'hidden' meaning of the divine name revealed to Moses to be the soteriological key which will allow him to equate knowing the Reality that is with being transformed by love into it:

'Such is finally the ultimate foundation of the difference between God and the created being. God is what he has, he is by himself; the created being is not what it has, it only has a borrowed being... Therefore, if in Augustine there is no possible equivocation between God's being and that of the created beings, there also isn't any real duality between them in this monism of Being inspired by Plotinus...' (Zum Brunn 1988, p.106-7).

\section{Neoplatonic Mysticism in Thomas Aquinas (1225-1274) and Meister Eckhart (1260-1327)}

Zum Brunn concedes that there is nothing new in Augustine's ontological interpretation of Ex. 3.14 - there had been a long tradition of identifying 'He who is' with Being per se in the Greek and Latin Fathers ever since Philo of Alexandria (Zum Brunn 1988, p.109-110). Augustine's originality, she suggests, is in the abundant use he makes of the verse, the explicit links he draws between it and the ego eimi of John's Gospel ${ }^{32}$ and, not least, in the stimulus he gave to medieval discussions of the divine name. ${ }^{33}$ It is to two of these discussions that we will now turn to show how Augustine's ChristianPlatonist reading of the name revealed to Moses is picked up and reworked according to the distinctive emphases of two medieval Dominicans - St Thomas Aquinas and Meister Eckhart. Both continue to work with Augustine's (Parmenidean) ontology of 'that which is' as opposed to 'that which is not', in other words, of Being and nothingness, ${ }^{34}$ immutability and change ${ }^{35}$ and eternity and temporality, and both will continue to emphasise the Neoplatonic (and Vedāntic) theme of the relatedness of knowledge and being, of the creature's 'is-ness' and the divine 'I am'. Indeed, John Hick goes so far as to claim that:

\footnotetext{
${ }^{31}$ See, e.g. In Iohannis evangelium 2,2. For more on the correspondences Augustine draws between Ex. 3:14 and Gospel passages like Romans 1:20, cf. Zum Brunn 1988, p.110-111.

${ }^{32}$ Zum Brunn points out that Augustine was the first of the Latin Fathers to explicitly relate Ex. 3:14 to the 'I am' sayings in the Fourth Gospel and that this parallel was also not found in the Greek Fathers before John Chrysostom (349-407), who was contemporary with Augustine (cf. Zum Brunn 1988, p.109-114).

${ }^{33}$ Cf. also Beierwaltes 1972, p.38: 'Dem Mittelalter ist Augustinus eine der großen Autoritäten. Dadurch ist mittelbar auch neuplatonisches Denken tradiert und im eigentümlich neuen Ansatz am Leben erhalten und zugleich umgeformt worden'.

34 "I am who I am and you will say to the children of Israel: he who is has sent me to you"; which means that, compared to the one who truly is, because he is immutable, the changing created things are not; it is exactly what Plato asserted forcefully and taught without getting tired of it...' Augustine, City of God, 8.12. Cf. also Exp. Of Psalms. 134, 6.

35 '... only that which is not only not changed, but cannot undergo any change at all, can be called being in the truest sense without any scruple'. Augustine (1970), The Trinity, 5.2.3.
} 
'...it is not an exaggeration to say that during the early and medieval periods, the picture of the universe accepted by Christian mystics, and the forms of religious experience that they reciprocally reflected and shaped, were a series of echoes of Neoplatonism'. Elsewhere in the article the style has been to include the reference for the citation in brackets after the quote rather than as an endnote. In this case it would be (Hick 1999, p.144). ${ }^{36}$

While 'mysticism' was not a word used until the early-modern period to denote a specific conceptual or experiential category of Christian spirituality, mystikos was present from the beginnings of the Christian tradition as an epithet used to refer to what is 'hidden'-most often, the 'hidden' meaning of scripture. The idea of a 'mystical theology' tout court was not coined as a term until Dionysius's fifth-century treatise by the same name, and, in the Pseudo-Areopagite's insistence that the theo-logic (i.e. manner of speaking about God) he is espousing is as much a spiritual practice as it is an intellectual exercise, ${ }^{37}$ we can start to see how, over centuries, a term originally used to denote the 'real' or 'deeper' meaning of divine self-revelation in texts also came to signify something closer to what Hick has in mindnamely, to a 'mystical' experience of union with God. ${ }^{38}$ In other words, coming closer to the 'hidden' meaning of scripture does not involve merely rational exegesis but a wholehearted attempt to draw closer to the God who is simultaneously revealed and hidden there. ${ }^{39}$

That the word 'mystical' did come to acquire connotations of union with ultimate reality and that it did so in the Christian tradition at least partly via the mediating thought of Pseudo-Dionysius (c. late fifth-early sixth century CE) is not a coincidence, but one of the profound 'echoes of Neoplatonism' to which Hick refers. ${ }^{40}$ This is not to claim that every individual whom the Christian tradition would tend to recognise as a 'mystic' has also been a Neoplatonist ${ }^{41}$ (at least not self-consciously) or that the metaphysical-experiential notion of 'union' with the divine must necessarily always be parsed in terms of Neoplatonic philosophy, but simply to suggest that for many Christian mystics in the early and medieval periods, the 'picture of the universe that they accepted' and the 'forms of religious experience that they reflected and shaped' were, indeed, deeply influenced by Platonic themes and insights - and this is certainly true of Aquinas and Eckhart.

Just as Augustine is struck at the start of his Confessions by the same paradox which had confronted Moses - of how we can call upon God without knowing him, and how we can know God without calling upon him (Augustine

\footnotetext{
$\overline{36}$ John Hick, The Fifth Dimension. Oxford Oneworld, Hick 1999, 144.

37 ....with your understanding laid aside... strive upward as much as you can towards union with him who is beyond all being and knowledge. By an undivided and absolute abandonment of yourself and everything, shedding all and freed from all, you will be uplifted to the ray of the divine shadow which is above everything that is'. (Pseudo-Dionysius, Mystical Theology, 997B-1000A).

${ }^{38}$ Hick, ibid., 136. For more on this, see McGinn 1991, xiv. For the history of the word 'mysticism', see Bouyer 1980.

${ }^{39}$ This refusal to see scriptural exegesis as some kind of ostensibly 'neutral' academic exercise helps to dissolve the question of whether a particular interpretation is a faithful reading 'of' or a subjective reading 'into' a verse or passage - an anachronistic pseudo-problem well dismantled by R. Dobie in his article 'Thomas Aquinas and Meister Eckhart on Exodus 3:14: Exegesis or Eisegesis?', Medieval Mystical Theology 24.2 (Dobie 2015), 124-36.

${ }^{40}$ On the Neoplatonism of Pseudo-Dionysius specifically, and how this later became influential on Thomas Aquinas, see O'Rourke 2005.

${ }^{41}$ Obviously, most Neoplatonists were not Christians.
} 
2008, I.1) - so Aquinas wrestles with the twin horns of the dilemma of 'knowing God' and 'naming God' in Questions 12 and 13 of the Prima Pars of his Aquinas Summa Theologiae (1964-1980). He concludes his question of how we can speak of God by arguing that 'The One who Is' is the most appropriate name for God, and he gives the following three reasons for thinking so (Aquinas 1964-1980, I.13.11): Firstly, because '...it does not signify any particular form, but existence itself. Since the existence of God is his essence, and since this is true of nothing else...it is clear that this name is especially fitting for God...'; secondly, Aquinas argues, it is the most 'universal' name we can apply to God because it does not restrict God to any particular mode of being, but refers to God as 'an infinite ocean of being...infinite and unlimited...[which] comprehends all in himself'. Thirdly, Ex. 3.14 offers us the best way of talking about God because it signifies 'being in the present' since tense cannot be applied to sheer Existence as such.

In his focus on God as the 'self-subsistent act of existence' (Aquinas 19641980 , I.4.2), through which all things 'are', Aquinas turns to Neoplatonic concepts in order to explain the sui generis nature of the causation involved in creation-that is, the very causing-to-be of creatures. This is why Cornelio Fabro argued that Thomas's commentary on the anonymous Liber de Causis-a work inspired by Proclus' Elements of Theology-was the 'final step in his absorption of Neoplatonism, 42 and, in particular, that Thomas's commentary on Proposition 18 of the De Causis represents 'the nucleus of the Thomistic metaphysics of causality' (Fabro, in O’Meara 1982, p.101). Here, Thomas explains that '...the first being [ens primum] gives being to all things by way of creation [per modum creationis]. But the first life, whatever that might be, does not give life by way of creation but by way of form'. ${ }^{43}$ In other words, while Augustine focused on the connotations of Ex. 3.14 in terms of divine eternity and immutability, Aquinas's emphasis rests on God as the pure activity of Being - the 'I am' by which all creatures are sustained and in which they reside. The implications are that:

'As the cause of all creatures outside of whom nothing would exist, one cannot take up a position "outside" of the relationship between cause and effect, Creator and creature. Rather, the human intellect can know anything about God only by participation in God's wisdom itself. We must "enter into" God's wisdom or Word in order to understand it, just as we must "enter into" the light in order to see the light' (Dobie 2015, p.126, original emphasis). ${ }^{44}$

\footnotetext{
${ }^{42}$ C. Fabro, 'The overcoming of the Neoplatonic triad of Being, Life, and Intellect by St Thomas Aquinas' in O'Meara 1982, p.97-108, here p.97.

43 Aquinas, Commentary on the Book of Causes, prop.18, in Guagliardo et al. 1996. Italics signify Aquinas quoting from the Book of Causes in his exposition.

${ }^{44}$ Fabro was one of the first critics to highlight the importance of 'participation' in Thomas' metaphysics — cf. 'Platonic causality is actuated as a participation that is the "presence" of the cause in the thing caused. Causality shows itself to be a defence and a recovery of the unity of the real insofar as the multiplicity of the effects is gathered into the unity of the cause'. (Fabro, ibid., 104). As we will see, Eckhart takes this notion of ontological unity between creature and Creator to its logical extreme.
} 
Aquinas was aware of the possible pantheistic implications of a theological metaphysics of ontological continuity from effect to Cause, but he is nevertheless quite clear that 'knowing' and 'being' cannot be wholly separated. Having cited Augustine in support, he explains in Q.12 of the Summa that, when it comes to 'seeing' or knowing anything, '...we do not see unless the thing seen is somehow in us' (Aquinas 1964-1980, I.12.2, reply). ${ }^{45}$ However, given that God cannot possibly be an 'object' of knowledge (since, as Dobie rightly notes, we 'cannot take up a position outside of the relationship between divine cause and created effect), '...when a created intellect sees God's essence, that very essence becomes the form through which the intellect understands', (Aquinas 1964-1980, I.12.5, reply) or, as Aquinas puts it more fully in his conclusion to Article 2:

'God's essence is existence itself. So, as other intelligible forms, which are not identical with their existence, are united to the mind by means of a sort of mental existence by which they inform and actualize the mind, the divine essence is united to a created mind so as to be what is actually understood, and through its very self it causes the mind actually to understand' (Aquinas 1964-1980, I.12.2).

While recognised without question as 'Christian', and, increasingly, as 'Platonist', Aquinas is rarely referred to as a 'mystic' and yet, notwithstanding the unembellished prose in which he conveys his thoughts, it is important to remember that this paradigmatic 'schoolman' was also committed day-by-day to the practice of finding God in word and prayer. In the 'hidden' meaning of Ex. 3.14 Aquinas recognises the 'I am' at the heart of his own 'I am' and it is by this divine light, he says, that 'a creature becomes godlike' (Aquinas 1964-1980, I.12.5) — even if this process only begins here on earth. ${ }^{46}$ To see how this theme can start to break through the boundaries of medieval Christian orthodoxy, we will now turn to Thomas's Dominican confrere, Meister Eckhart, who goes beyond both Augustine and Aquinas since '... it is a question', as Zum Brunn puts it, "for the Rhenish Dominican of "becoming God" by becoming being'. (Zum Brunn 1988, x.).

When it comes to Eckhart, we have reached the quintessential example of a Christian mystic influenced by Neoplatonism. In his Book of the Parables of Genesis, he explains that his aim is to '...bring to light the more hidden sense of some things contained in them [the parables of Genesis] in parabolic fashion "under the shell of the letter", 47 and he has no problem in using pagan philosophy to help him to do so. ${ }^{48}$ In his reading of Ex. 3.14, Eckhart analyses each word in the Ego sum qui sum. ${ }^{49}$ Echoing

\footnotetext{
${ }^{45}$ The quotation taken from Augustine (1970) is from De Trinitate 9.11: 'A likeness of God comes to be in us when we know him'.

${ }^{46}$ For a recent volume on these issues, see Blankenhorn 2015.

${ }^{47}$ Eckhart, In Gen. II, n.1 in Colledge and McGinn 1981, p.92.

48 'No one can be thought to understand the scriptures who does not know how to find its hidden marrow Christ, the Truth...enclosed there [in its parables] are to be found the virtues and the principles of the sciences, the keys to metaphysics, physics and ethics, as well as the universal rules' Eckhart, In Gen. II, n.3, in Colledge and McGinn 1981, p.94.

${ }^{49}$ Eckhart, In Exod., nn.14-15 in McGinn 1986, p.45-8.
} 
Aquinas' first reason for seeing 'He who is' as the most appropriate divine name, Eckhart interprets the 'I' as 'pure substance' without reference to accident or form, and in absolute distinction from everything else which exists through him. While finite beings are a 'this or a that' (esse hoc et hoc) and defined by their not being something else, God is Being itself (esse simpliciter), distinct by virtue of his 'indistinction' from anything else. ${ }^{50}$ In this way, where Augustine focussed on immutability and transcendence, and Aquinas on Existence as act, Eckhart underlines above all the unity and simplicity of the One. ${ }^{51}$ In the 'AM', Eckhart sees the identity of existence and essence in the divine Being - the sui generis equivalence which is precisely what allows God to be both immanent in and transcendent to all created beings, both distinct and indistinct at the same time. Eckhart does not understand God as the 'totality of being(s)' in a pantheistic sense, but as 'Being' — which is, therefore, 'not-other' than any created being, but not identical with any one of those beings either:

'The relationship of creative Being to created beings can only be articulated as a paradox: on the one hand, Being itself is the innermost Ground of the being and existence of creatures; it is, for that reason, what is most intimate in beings, is everywhere and "in" all things, and not distinct from anything... on the other hand and at the same time, however, it is "beyond" all beings, is no-thing and precisely as such the Ground of each thing'. (Beierwaltes 1972, p.61-2, my translation). ${ }^{52}$

Finally, Eckhart explains the 'WHO' as a non-finite relative pronoun which gestures towards the open-ended and boundless substance of the divine Being.

The relation between creature and Creator for Eckhart is neither one of simple identity nor one of straightforward difference. In his Latin sermon on grace, it is possible to hear an echo of Ex. 3.14 when he says that it is 'by God's grace [that] I am what I am' (his rendering of 1 Cor. $15: 10)^{53}$ — the pure being (istichkeit) in which we are enjoined to participate through grace in Christ and apart from which we are 'pure nothing, ${ }^{54}$ The more 'indistinct' we can become through material and spiritual detachment, the more we come to realise our non-difference from Being as such:

"When my "is" and "God's is", my "I am" and God's "I am" are one and the same "I am Who am", then there is one being, one knowing, and one working that is “greatly fruitful” like grace' (Dobie 2015, p.134-5). ${ }^{55}$

\footnotetext{
${ }^{50}$ As Beierwaltes points out, the Liber de Causis was also an important influence on Eckhart, and the Dominican often cites Proposition 21 ('The First Cause is sufficient in itself and is the most sufficient') in support of his emphasis on God as esse simpliciter (cf. Beierwaltes 1972, p.40, n.158).

51 'Als reine Substanz oder als reines Sein ist Gott Selbstgenugsamkeit, dives per se, "reich durch sich selbst", wie Eckhart immer wieder in Anlehnung an den neuplatonischen bestimmten Prinzip-Begriff des 'Liber de Causis' sagt'. Beierwaltes 1972, p.44.

52 'Das Verhältnis des schaffenden Seins zum geschaffenen Seienden kann sprachlich nur paradox formuliert werden: Einmal ist das Sein selbst der innerste Existenz- und Wesens-Grund des Seienden; es ist deshalb 'zuinnerst' im Seienden, überall und 'in' allem, gerade nichts vom Seienden 'Unterschiedenes'...zum andern und zugleich aber ist es 'über' allem Seienden, ist nicht-Etwas und gerade so Grund eines jeden Etwas...'

53 Sermon XXV, n.257, in McGinn 1986, p.218.

${ }^{54}$ Eckhart, cited in In agro dominico art.26: 'Omnes creaturae sunt unum purum nihil: non dico, quod sint quid modicum vel aliquid, sed quod sint unum purum nihil'. Colledge and McGinn 1981, p.80.

55 cf. Sermon 83, Colledge and McGinn 1981, p.207-8.
} 
In the 'hidden' meaning of the name revealed to Moses, Eckhart sees the key to mystical union with the source and ground of our existence. His arresting language of the 'nothingness' of created being, his distinction between God and the 'Godhead' beyond God, ${ }^{56}$ and his statements regarding the 'birth of the Word in the soul' ${ }^{57}$ which seem to blur the ontological distinction between creature and the Creator, display his indebtedness to Neoplatonic concepts (e.g. of a scale of being and a hyper-essential One), but arguably leave him teetering on the brink of Christian orthodoxy. Indeed, McGinn suggests that it cannot be merely coincidental that two of the three 'most systematic' Latin Neoplatonist Christian thinkers-John Scotus Eriugena and Eckhart himself - were both posthumously condemned by the Church for certain of their more provocative ideas:

'Such condemnations and suspicions seem to confirm the feeling that Neoplatonic thought is at best a problematic (and frequently an unhelpful) language for the expression of Christian theology' (McGinn in O'Meara 1982, p.128). ${ }^{58}$

The issue of how helpful or problematic Neoplatonic thought might be as a vehicle for expressing Christian theology is not one I intend to address explicitly, since my aim has been more modest - namely, to demonstrate its influence on several key Christian figures, especially in their reading of the 'I AM' of Ex.3.14. I have also sought to suggest, however, that there is, at the very least, a possible tension between Neoplatonic and Christian ontologies when it comes to the issue of how 'beings' are related to Being. ${ }^{59}$ While Augustine and Aquinas manage to pull back from the brink of a thoroughgoing identity between creature and Creator by postponing any such mystical union until after death, ${ }^{60}$ the language of conversion, participation and even transformation is evident in both of these paragons of orthodoxy. Eckhart is more daring in his imagery and conceptual vocabulary, and it is, therefore, not his mysticism or Neoplatonism which has come under suspicion, but the orthodoxy of his Christianity. Finally, I want to look at what happens when the mystical correlation of 'knowing' and 'being' is pushed to its logical limits by turning to a twentieth-century figure who saw himself as both a (Platonist) Christian, and as a (Hindu) Vedāntin.

\section{Henri Le Saux (1910-73)}

Better known as Swami Abhishiktānanda, Henri Le Saux was a Benedictine monk who spent much of his life wrestling with the conceptual and spiritual attempt to reconcile

\footnotetext{
${ }^{56}$ For a detailed examination of this supposed distinction in Eckhart, see McGinn 1981.

${ }^{57}$ See In agro dominico, art.22.

${ }^{58}$ Indeed, McGinn specifically points out that ' $[\mathrm{t}]$ he majority of the twenty-eight propositions from his [Eckhart's] works condemned by Pope John XXII in the Bull "In agro dominico" of March 27, 1329, involve or imply aspects of his appropriation of Neoplatonism'. (129). The third Latin Neoplatonist McGinn has in mind (who was not condemned) is (Cardinal) Nicholas of Cusa (1401-1464).

${ }^{59}$ This tension can be explained partly by the Christian doctrine- not present in Neoplatonism—of creatio ex nihilo.

${ }^{60}$ Though, Augustine seems to have had a 'mystical' experience of union in a villa in Ostia.
} 
Christian theology with the non-dual (advaita) philosophy of Vedāntic Hinduism - a struggle which can be seen in microcosm in his treatment of Ex. 3.14. ${ }^{61}$

Like the Platonist-influenced Christians we have discussed so far, Le Saux's first move is to identify the search for the Ground of Being with the search for God:

'To every problem with which the jūanni is faced, to every metaphysic with which he is confronted, he replies by asking the simple question: "Do you, or do you not, admit the fact of Being? If there is Being, then who or what could qualify it?" This was long ago the theme of the famous poem of Parmenides at the dawn of Greek philosophy, shortly after the rishis on the banks of the Ganges and the Indus had themselves also heard in the depths of their spirit the upanișad of Being and Brahman. Reason may discuss, but experience knows'. (Abhishiktananda 1974, p.44). ${ }^{62}$

We can already begin to see from this passage why it may be unhelpful to ask whether Le Saux was primarily influenced by (Neo)-Platonism or Vedānta, since, like W. Jones two centuries earlier, he is identifying a common thread running between the traditions owing to their shared onto-theological characterisation of the divine Being. He is also influenced by all three of the figures we have looked at, sometimes even naming them explicitly. Like Augustine, he emphasises the immutability and eternity of the God revealed to Moses on Mount Horeb and the Indic sages in the Himalaya:

'He who $i$ - - beyond all such manifestations - can never change or disappear. He remains forever because he is. Once the realization that "I am" has dawned upon a man, he lives from then on at a level of awareness that no threat of extinction can ever touch'. (Abhishiktananda 1974, p.24).

Like Aquinas, he explains knowledge of God as a kind of 'connaturality', ${ }^{63}$ and, like Eckhart, he recognises the indistinct and limitless simplicity of God-Being:

'It is precisely because God is beyond form, that he is also behind and within every form; because he is formless, $a$-rūpa, he can be recognised and worshipped under every kind of form, sarva-rüpa. He is both the Unnameable and the possessor of every name, as in the hymn of Gregory of Nazianzen. There is nothing that does not manifest God to the soul which is open to him in a deep awareness of itself, and at the same time, there is nothing which, in revealing him, does not point to his being inexorably beyond'. (Abhishiktananda 1974, p.4-5).

\footnotetext{
${ }^{61}$ For an autobiographical account of his efforts at living a more inculturated form of Indian Christianity, see Monchanin and Abhishiktananda 1964, and for the standard biographical account of his life, see Du Boulay 2005.

${ }^{62}$ By upaniṣad here, he means a correspondence or even 'mystical correlation': 'The fundamental upanișad of the Hindu experience is between self and being, between the individual and the all, between atman and brahman, the formula which unfolds the ultimate secret of being...' (Abhishiktananda 1974, p.44, n.3).

63 'Only when man realizes that he himself is an inscrutable mystery - that is, that his true being lies beyond any thought or consciousness that he may have of himself - only then can he discover in the depths of his experience the inscrutable mystery of God. Man's unknowable being is of the same order as God's, for man comes from God and has been created in his image. His is the 'beyond all' of Being itself'. Abhishiktananda 1974, p.4 (referring to Aquinas 1964-1980, II-II, 45, 2).
} 
Where he pushes the insights of his Christian predecessors to a logical extreme, however, is in rejecting what he sees as a misplaced Christian reluctance-evident in Augustine and Aquinas, though perhaps less so in Eckhart - to fully embrace the 'nototherness' (advaita) of creature and Creator entailed (as he thought) by the correlation between God and Being, and to stubbornly keep seeking for a distinct place from where one's 'I' can contemplate God's 'Thou':

"...even the remotest and most inaccessible "caverns" of his heart turn out to be occupied already, and the darkness in which he had hoped to save his personal existence from annihilation in Being is already ablaze with the glory of God. He still struggles desperately to utter an I, a Thou; but now no sound makes itself heard, for where indeed could it come from? And even if by some means this $I$ were to be pronounced, it would immediately be submerged in the one I AM that fills eternity...' (Abhishiktananda 1974, p.63).

This is the fundamental challenge that advaita Vedanta-and certain forms of Neoplatonism - present to Christian theology: if all is Being and anything other than or 'outside' Being is pure nothingness, it becomes difficult to see how there can be any real encounter in an ultimate sense between my 'I am' and God's 'I am'. Indeed, significant figures within Vedāntic traditions have seen this 'not-otherness' between creature and Creator as the obvious meaning of the Exodus verse upon which we have been concentrating. The well-known twentieth century Advaitin, Ramana Maharshi (1879-1950), claimed that the whole of Vedānta is contained in two biblical passages: 'Be still and know that I am God' (Ps. 46:10) and 'I am that I am' (Friesen 2015, p.35). This is perhaps unsurprising, given that Ramana based his own spiritual teaching on the search for self-knowledge and self-realisation - enigmatically encouraging enquiring disciples to return to the source of their spiritual questions and reflect on the nature and identity of the 'I' who is asking them. Abhishiktānanda expresses this conclusion powerfully:

'Once the Absolute is met, there is no firm ground on which man might try to keep his balance. Once in contact with Being, all that dares to claim that it has a share in Being falls into nothingness, or rather disappears into Being itself. When the Self shines forth, the I that has dared to approach can no longer recognize its own self or preserve its own identity in the midst of that blinding light. It has so to speak vanished from its own sight. Who is left to be, in the presence of Being itself? The claim of Being is absolute...All the later developments of the Covenant religion - doctrines, laws and worship - are simply met by the advaitin with the word originally revealed to Moses on Mount Horeb: I am that I am'. (Abhishiktananda 1974, p.45).

\section{Conclusion}

While it might seem like a long and circuitous route to travel from Egypt to India, via Mount Horeb, we have seen that the holy ground of Moses's encounter with God at the 
burning bush provides us with fertile soil for exploring the connections between two great philosophical traditions of the ancient world. Scholars have long been fascinated by perceived similarities between the Neoplatonism which flourished in the early centuries of the Common Era in Alexandria and the Sanskritic wisdom of the Upanișads. Whether common themes are the result of actual historical borrowings or cross-fertilisation is a difficult question to answer, and we have not sought to take a position on this either way. What I have argued, however, is that certain resonant parallels run deep and are far more than merely superficial connections between the two systems. In particular, we have explored the implications of a metaphysics of ontological non-dualism between the many and the One based, in both Neoplatonism and Advaita Vedānta, on an identification of the Absolute with Being as such. While other studies have concentrated on fine-grained examinations of commonalities and divergences, I have looked at these broad comparative questions through the prism of a single verse in the Hebrew scriptures and its long interpretation history. The divine 'I AM' of Ex. 3.14 has been drawn on by both Christians and Vedāntins in support of a particular understanding of the relation between God (Being) and world (beings). Indeed, in his seminal comparative study of mysticism 'east' and 'west', Rudolf Otto draws specifically on Ex. 3.14 in order to substantiate his case that Samkara and Eckhart, while separated by time and geography, were nevertheless working with 'an almost identical metaphysic' (Otto 1932, p.4). It is a metaphysic found in Neoplatonism and Vedānta which identifies God with Being, and Being with God, without determination or distinction, and which thus accords ontological priority to the One over the many. This is why Otto can claim that Eckhart, no less than Samkara, could take the sixth chapter of the Chāndogya Upanișad as his starting-point: 'Being only was this in the beginning, one only without a second' (Otto 1932, p.4). ${ }^{64}$ It is also a metaphysic which is present, if perhaps underemphasised, in certain dimensions of the Christian traditions - as we have seen in Augustine, Aquinas, Eckhart and Abhishiktānanda. These four thinkers have provided us with interpretations of Ex. 3.14 which allow us to see the common onto-theological thread between Neoplatonism and Advaita Vedānta. While Augustine and Aquinas teeter on the edge of a full-blooded non-dualism between creature and Creator, Eckhart and Abhishiktānanda follow through the implications of Neoplatonic and Vedāntic metaphysics to their logical conclusion-we know God by recognising that we are-not-other-than God. The differences we have seen in the four figures we have looked at result not primarily from differences between Neoplatonism and Vedānta, but from differences between the ontological relation of $a$-dvaita between the One and the many to which both of these systems point and the distinction between God and creature which Christianity wants to maintain. As McGinn has noted, the fact that Christians who have embraced the consequences of Neoplatonism, such as Eriugena and Eckhart, have had their orthodox credentials put under question, suggests that there are points at which Christian doctrine diverges from Neoplatonic metaphysics. The same could be said, mutatis mutandis, for the attempts of figures like Swami Abhishiktānanda to assimilate Christian belief with the philosophical tenets of Vedānta. If we see a certain Christian emphasis on 'distinction' as our 'control' in this conceptual experiment, however, the fact that both Neoplatonism and Vedānta result in similar tensions lends support to the conclusion: that there are indeed

$\overline{{ }^{64} \text { From Chāndogya 6.2.1: sat eva }}$ idam agre āsìt ekam eva advitīyam. 
deep conceptual parallels between these forms of Greek and Indian idealisms - and this may be even more startling if they are not the result of actual historical interactions, for then they would point to what Otto recognised as '.... an astonishing conformity in the deepest impulses of human spiritual experience, which-because it is almost entirely independent of race, clime and age - points to an ultimate inward hidden similarity of the human spirit...' (Otto 1932, v).

Open Access This article is licensed under a Creative Commons Attribution 4.0 International License, which permits use, sharing, adaptation, distribution and reproduction in any medium or format, as long as you give appropriate credit to the original author(s) and the source, provide a link to the Creative Commons licence, and indicate if changes were made. The images or other third party material in this article are included in the article's Creative Commons licence, unless indicated otherwise in a credit line to the material. If material is not included in the article's Creative Commons licence and your intended use is not permitted by statutory regulation or exceeds the permitted use, you will need to obtain permission directly from the copyright holder. To view a copy of this licence, visit http://creativecommons.org/licenses/by/4.0/.

\section{References}

Abhishiktananda, S. (1974). Saccidānanda: a Christian approach to advaitic experience. Delhi: ISPCK. App, U. (2009). William Jones's ancient theology. Philadelphia: University of Pennsylvania.

Aquinas, T. (1964-1980). Summa Theologiae. Blackfriars edition. London: Eyre \& Spottiswoode, and New York: McGraw-Hill Book Company.

Augustine. (1970). The Trinity. McKenna, Stephen (trans.). Washington, D.C: Catholic University of America Press.

Augustine. (1979). In P. Schaff(Ed.), Expositions on the Book of Psalms. Grand Rapids, Michigan: Eerdmans. Augustine. (2008). Confessions, Chadwick, Henry (trans.). Oxford: OUP.

Beierwaltes, W. (1972). Platonismus und idealismus. Frankfurt am Main: Vittorio Klostermann.

Blankenhorn, O. P. B. (2015). The mystery of union with god: Dionysian mysticism in Albert the Great and Thomas Aquinas. Washington, D. C: Catholic University of America Press.

Boland, V. (1996). Ideas in God according to Saint Thomas Aquinas. New York: E.J. Brill.

Bouyer, L. (1980). Mysticism: An essay on the history of the word. In R. Woods (Ed.), Understanding mysticism (pp. 42-55). Garden City, NY: Doubleday Image Books.

Cannon, G. H. (Ed.). (1970). The letters of Sir William Jones. Oxford: Clarendon Press.

Clarke, W. N. (2009). The creative retrieval of Saint Thomas Aquinas: Essays in Thomistic philosophy, new and old. New York: Fordham University Press.

Colledge, E., \& McGinn, B. (Eds.). (1981). Meister Eckhart: The essential sermons, commentaries, treatises and defence. London: Paulist Press.

Coxon, A. H., \& McKirahan, R. (Ed. and Trans.) (2009). The fragments of parmenides. A critical text with introduction and translation, the ancient testimonia and a commentary. Las Vegas: Parmenides Publishing.

Dobie, R. J. (2015). Thomas Aquinas and Meister Eckhart on Exodus 3:14: exegesis or eisegesis? Medieval Mystical Theology, 24(2), 124-136.

Du Boulay, S. (2005). The cave of the heart: The life of Swami Abhishiktananda. Maryknoll, N.Y: Orbis Books.

Friesen, J. G. (2015). Abhishiktananda (Henri Le Saux): Christian Nondualism and Hindu Advaita. Calgary, Alberta: Aevum Books.

Gregorios, P. (2002). Neoplatonism and Indian philosophy. Albany, NY: State University of New York Press.

Grimes, J. A. (2004). The Vivekacūụāmaṇi of Śankarācārya Bhagavatpāda: an introduction and translation. Aldershot, UK, Burlington, VT: Ashgate.

Guagliardo, V. A., Hess C. R., \& Taylor, R. C., trans. (1996). Commentary on the Book of Causes/St. Thomas Aquinas. Washington, D. C.: Catholic University of America Press.

Hacker, P. (1995). Cit and nous, or the concept of Spirit in Vedantism and Neoplatonism. In W. Halbfass (Ed.), Philology and confrontation: Paul Hacker on traditional and modern Vedānta (pp. 211-226). Albany, NY: State University of New York Press. 
Harris, R. B. (Ed.). (1981). Neoplatonism and Indian thought. Virginia: State University of New York Press. Hick, J. (1999). The fifth dimension. Oxford: Oneworld.

Just, M. (2013). Neoplatonism and paramadvaita. Comparative Philosophy, 4(2) Article 6.

Kopf, D. (1969). British Orientalism and the Bengal Renaissance: The dynamics of Indian modernization 1773-1835. Berkeley and Los Angeles: University of California Press.

Lott, E. J. (1980). Vedantic approaches to God. Macmillan: Library of Philosophy and Religion. London.

Malkovsky, B. (2001). The role of divine grace in the soteriology of Sankaracarya. Leiden: Brill.

Max-Müller, F. (1919). The six systems of Indian philosophy. Varanasi: Vidya Vilas Press and London: Longmans, Green and Co.

McGinn, B. (1981). The God beyond God: theology and mysticism in the thought of Meister Eckhart. The Journal of Religion, 61, 1-19.

McGinn, B. (Ed.). (1986). Meister Eckhart, teacher and preacher. New York: Paulist Press.

McGinn, B. (1991). The foundations of mysticism. London: SCM.

Monchanin, J., \& Abhishiktananda. (1964). A Benedictine Ashram. Douglas, Isle of Man: Times Press.

O’Meara, D. J. (Ed.). (1982). Neoplatonism and Christian thought. Albany: State University of New York Press.

O’Rourke, F. (2005). Pseudo-Dionysius and the metaphysics of Aquinas. ND: University of Notre Dame Press.

Otto, R. (1932). Mysticism east and west: a comparative analysis of the nature of mysticism. London: Macmillan and Co..

Pandey, U. (2015). Śankara: a realist philosopher. Jalandhar: Kautilya Prakashan.

Perl, E. (2014). Thinking being: introduction to metaphysics in the classical tradition. Leiden; Boston: BRILL.

Plotinus. (1984/1988). Ennead V and VI (Loeb). Trans. A.H. Armstrong . Cambridge, Mass: Harvard and London: Heinemann.

Soskice, J. (2014). Aquinas and Augustine on creation and god as "eternal being". New Blackfriars, 95(1056), $190-207$.

Staal, J. F. (1961). Advaita and Neoplatonism: a critical study in comparative philosophy. University of Madras.

Zum Brunn, É. (1988). St. Augustine: Being and nothingness. New York: Paragon House.

Publisher's Note Springer Nature remains neutral with regard to jurisdictional claims in published maps and institutional affiliations. 